\title{
REPOSISI PENYEDIAAN JASA PEKERJA/BURUH PADA PERUSAHAAN SUATU TINJAUAN PUTUSAN MAHKAMAH AGUNG NOMOR 1438 K/PDT.SUS.PHI/2017
}

\author{
Erna Dwi Rachmawati, S.H. \\ Program Pasca Sarjana - Magister Hukum \\ Universitas Semarang \\ Email: ernaundip@gmail.com
}

\begin{abstract}
ABSTRAK
Perkembangan ekonomi global dan kemajuan teknologi yang begitu cepat berdampak pada timbulnya persaingan usaha yang begitu ketat dan terjadi hampir di semua sektor. Lingkungan yang sangat kompetitif ini menuntut dunia usaha untuk menyesuaikan dengan tuntutan pasar yang memerlukan tanggapan yang cepat dan fleksibel dalam meningkatkan pelayanan kepada pelanggan. Dalam kaitan ini dapat dimengerti apabila kemudian muncul kecenderungan perusahaan untuk menyerahkan sebagian pelaksanaan pekerjaan kepada perusahaan lain, satu bagian atau beberapa bagian kegiatan perusahaan kepada perusahaan lain melalui perjanjian penyediaan jasa pekerja/buruh.

Perumusan masalahnya adalah bagaimana pengaturan penyediaan jasa pekerja/buruh pada perusahaan, dan bagaimana reposisi penyediaan jasa pekerja/buruh pada perusahaan pasca Putusan Mahkamah Agung Nomor 1438 K/PDT.SUS.PHI/2017. Tujuan penelitian untuk mengetahui dan memahami tentang penyediaan jasa pekerja/buruh pada perusahaan, serta posisinya pasca Putusan Mahkamah Agung Nomor 1438 K/PDT.SUS.PHI/2017.

Metode penelitian yang digunakan adalah yuridis empiris, dalam mengadakan pendekatan, prinsip-prinsip dan peraturan-peraturan yang masih berlaku dipergunakan dalam meninjau dan melihat serta menganalisa permasalahan yang menjadi objek penelitian, serta dalam mengadakan pendekatan dilakukan dengan melihat kenyataan yang ada dalam praktek.

Berdasarkan hasil penelitian dapat disimpulkan bahwa: 1) Untuk efisiensi dan efektifitas manajemen perusahaan, perusahaan dapat mengalihkan sebagian pekerjaan yang bukan merupakan pekerjaan utama kepada perusahaan penyediaan jasa pekerja/buruh, 2) Perusahaan penyediaan jasa pekerja/buruh harus berbentuk badan hukum, 3) Perjanjian kerja antara pekerja/buruh dengan perusahaan penyedia jasa pekerja/buruh dilakukan dengan Perjanjian Kerja Waktu Tertentu atau Perjanjian Kerja Waktu Tidak Tertentu, 4) Apabila pelaksanaan perjanjian penyediaan jasa pekerja/buruh tidak sesuai dengan peraturan perundang-undangan, maka status pekerja beralih menjadi pekerja dari perusahaan penyedia pekerjaan.

Kata kunci: Pekerja/Buruh, Penyediaan Jasa Pekerja/Buruh, Perjanjian Kerja.
\end{abstract}




\title{
REPOSITION OF WORKERS / WORK SERVICES PROVIDING IN COMPANIES \\ A REVIEW OF THE SUPREME COURT DECISION NUMBER 1438 K/PDT.SUS.PHI/2017
}

\author{
Erna Dwi Rachmawati, S.H. \\ Post Graduate Program - Master of Law \\ University of Semarang \\ ernaundip@gmail.com
}

\begin{abstract}
The rapid development of the global economy and technological advancements have resulted in the emergence of intense business competition and occur in almost all sectors. This highly competitive environment requires businesses to adapt to market demands that require a fast and flexible response in improving customer service. In this connection it is understandable if a company tends to submit a portion of the work to another company, one part or several parts of the company's activities to another company through an agreement to provide workers' services.

The problem formulation is how to regulate the provision of services of workers / laborers to companies, and how to reposition the provision of services for workers / laborers to companies after the Decision of the Supreme Court Number 1438 K/PDT.SUS.PHI/2017. The purpose of the research is to know and understand about the provision of services for workers / laborers in the company, as well as their position after the Decision of the Supreme Court Number 1438 K/PDT.SUS. PHI/2017.

The research method used is empirical juridical. In making approaches, the principles and regulations that are still valid are used in reviewing and viewing and analyzing the problems that are the object of research. And, in making approaches carried out by looking at the reality in practice.

Based on the results of the study, it can be concluded that: 1) For the efficiency and effectiveness of company management, the company can divert part of the work that is not the main job to the workers providing services, 2) The company providing labor services must be a legal entity, 3) Agreement work between workers / laborers and companies providing services for workers / laborers is carried out with Specific Time Work Agreements or Unspecified Time Work Agreements, 4) If the implementation of the agreement on providing workers / laborers services is not in accordance with the laws and regulations, then the status of workers becomes workers of job provider company.
\end{abstract}

Keywords: Workers / Laborers, Workers / Labor Services Providing, Employment Agreements. 
LATAR BELAKANG

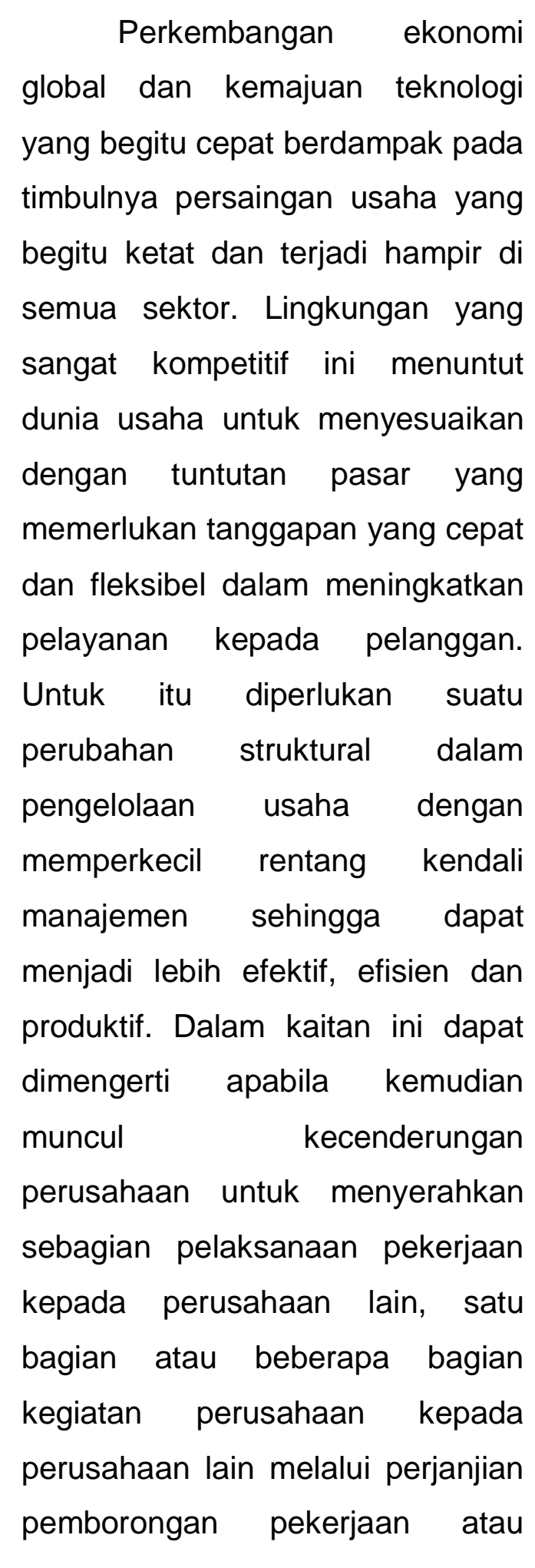

perjanjian penyediaan jasa

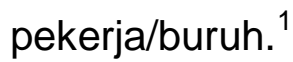

Ketentuan pemborongan pekerjaan diatur dalam Pasal 1601b Kitab Undang-Undang Hukum Perdata "Perjanjian pemborongan kerja ialah suatu persetujuan bahwa pihak kesatu, yaitu pemborong, mengikatlan diri, untuk menyelesaikan suatu pekerjaan bagi pihak lain, yaitu pemberi tugas, dengan harga yang telah ditentukan". ${ }^{2}$ Namun dalam Pasal tersebut belum diatur mengenai perlindungan bagi pekerja/buruh yang dipekerjakan melalui pemborongan pekerjaan maupun penyediaan jasa pekerja/buruh. Oleh karena itu, Undang-Undang Nomor 13 Tahun 2003 tentang Ketenagakerjaan

\begin{tabular}{l}
\hline 1 Jaringan Dokumentasi Dan \\
Informasi Hukum, Surat Edaran Menteri \\
Tenaga Kerja Dan Transmigrasi Republik \\
Indonesia Nomor: SE.04/MEN/VIII/2013 \\
tentang Pedoman Pelaksanaan Peraturan \\
Menteri Tenaga Kerja Dan Transmigrasi \\
Republik Indonesia Nomor 19 Tahun 2012 \\
tentang Syarat-Syarat Penyerahan Sebagian \\
Pelaksanaan Pekerjaan Kepada Perusahaan \\
Lain, \\
$\frac{\text { https://idih.kemnaker.go.id/data puu/SE 04 }}{2013 . P D F .}$ \\
${ }^{2}$ Kitab Undang-Undang Hukum \\
Perdata.
\end{tabular}


mengatur mengenai penyerahan sebagian pelaksanaan pekerjaan kepada perusahaan lain.

Undang-Undang Dasar

Negara Republik Indonesia tahun 1945, Pasal 27 ayat (2) disebutkan bahwa "Tiap-tiap warga negara berhak atas pekerjaan dan penghidupan yang layak bagi kemanusiaan". ${ }^{3} \quad$ Untuk melaksanakan apa yang menjadi tujuan dari bunyi pasal tersebut, maka pemerintah memutuskan salah satu peraturan yang mengatur tenaga kerja di Indonesia, yaitu Undang-Undang Nomor 13 Tahun 2003 tentang Ketenagakerjaan.

Hal baru yang diatur dalam Undang-Undang Ketenagakerjaan tersebut adalah mengenai pemborongan pekerjaan atau penyediaan jasa pekerja/buruh.

Ketentuan mengenai Perjanjian Penyediaan Jasa Pekerja/Buruh diatur dalam Undang-Undang Republik Indonesia Nomor 13 tahun 2003

${ }^{3}$ Redaksi Bmedia, UUD 1945 \& Perubahannya; Reshuffle Kabinet Kerja (20142019), (Jakarta: Bmedia Imprint Kawan Pustaka, 2017), HIm. 30. tentang

Ketenagakerjaan, khususnya Pasal 64, Pasal 65, Pasal 66

Pekerja/buruh adalah salah satu pihak yang lemah, dimana pekerja/buruh membutuhkan pekerjaan tanpa bisa menuntut hak-hak pekerja/buruh, karena kekuatiran akan kehilangan pekerjaan. Penyimpanganpenyimpangan yang sering ditemui dalam praktik Perjanjian Penyediaan Jasa Pekerja/Buruh, antara lain:

1. Jenis pekerjaan termasuk sebagai pekerjaan utama di perusahaan, dilimpahkan kepada perusahaan lain dengan perjanjian penyediaan jasa pekerja/buruh.

2. Jangka waktu perjanjian kerja antara perusahaan penyediaan jasa pekerja/buruh dengan pekerja/buruh dilaksanakan secara terus menerus tanpa mengindahkan ketentuan mengenai Perjanjian Kerja Waktu Tertentu atau Perjanjian Kerja Waktu Tidak Tertentu. Bahkan dalam praktik dapat ditemukan adanya 
pengakhiran perjanjian kerja secara sepihak oleh perusahaan pemberi kerja, tanpa melalui prosedur Pemutusan Hubungan Kerja sesuai ketentuan peraturan perundang-undangan.

3. Perusahaan pemberi kerja membebankan biaya jasa perusahaan penyediaan jasa pekerja/buruh kedalam tagihan upah pekerja/buruh, sehingga perusahaan penyediaan jasa pekerja/buruh akan memotong hak upah pekerja/buruh sebesar biaya jasa yang ditagihkan.

4. Tidak diikutkannya pekerja/buruh ke dalam program jaminan sosial tenaga kerja (BPJS Ketenagakerjaan dan BPJS Kesehatan).

Dengan adanya penyimpangan-penyimpangan tersebut, jelas sangat menguntungkan perusahaan pemberi kerja maupun perusahaan penyediaan jasa pekerja/buruh, dan sebaliknya sangat merugikan pekerja/buruh. Pekerja/buruh adalah pihak yang lemah, baik dalam hal pengetahuan maupun ekonomi, sehingga apabila terjadi kasus yang merugikan pekerja/buruh, sebagian besar mereka hanya menerima nasib tanpa bisa melakukan upaya hukum. Namun ada juga pekerja/buruh yang mempunyai keberanian untuk melakukan upaya hukum menuntut hakhaknya melalui Pengadilan Hubungan Industrial. Sebagian besar tuntutan pekerja/buruh dikabulkan oleh Hakim karena perusahaan melanggar ketentuan peraturan perundang-undangan secara normatif.

Contoh kasus yang telah mendapat keputusan tetap dalam Pengadilan Hubungan Industrial dan berlanjut ke tingkat Kasasi Mahkamah Agung, yang dimenangkan oleh Penggugat (pekerja/buruh) adalah:

1. Putusan Pengadilan Hubungan Industrial pada Pengadian Negeri Medan, Nomor Putusan 
204/Pdt.Sus-PHI/2016/PN

Mdn. ${ }^{4}$

2. Putusan Mahkamah Agung Republik Indonesia, Nomor Putusan 1438 K/Pdt.Sus$\mathrm{PHI} / 2017 .{ }^{5}$

\section{BAHAN DAN METODE PENELITIAN}

1. Metode Pendekatan

Pendekatan yang penulis gunakan dalam penelitian ini adalah metode pendekatan yuridis empiris atau yuridis sosiologis.

2. Spesifikasi Penelitian

Spesifikasi penelitian yang dipilih dalam penelitian ini berupa penelitian diskriptif analistis.

3. Sumber data a. Data Primer

1) Kitab Undang-Undang

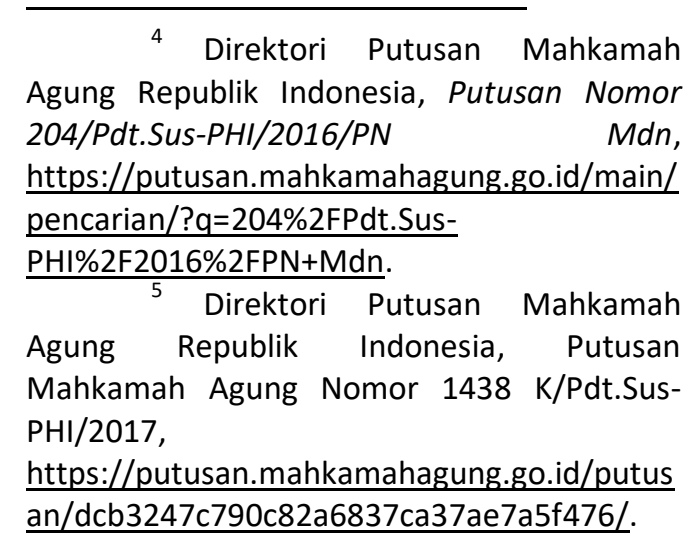

Hukum Perdata.

2) Undang-Undang Dasar Negara Republik Indonesia Tahun 1945.

3) Undang-Undang

Republik Indonesia

Nomor 13 Tahun 2003 tentang

Ketenagakerjaan.

4) Keputusan Menteri

Tenaga Kerja Dan

Transmigrasi Republik Indonesia Nomor:

KEP.100/MEN/VI/2004

tentang Ketentuan

Pelaksanaan Perjanjian

Kerja Waktu Tertentu.

5) Peraturan Menteri

Tenaga Kerja Dan

Transmigrasi Nomor 19

Tahun 2012 tentang

Syarat-Syarat

Penyerahan Sebagian

Pelaksanaan Pekerjaan

Kepada Perusahaan

Lain.

6) Surat Edaran Menteri

Tenaga Kerja Dan

Transmigrasi Republik

Indonesia Nomor:

SE.04/MEN/VIII/2013 
tentang

Pedoman

Pelaksanaan Peraturan

Menteri Tenaga Kerja

Dan Transmigrasi

Republik Indonesia

Nomor 19 Tahun 2012

tentang Syarat-Syarat

Penyerahan Sebagian

Pelaksanaan Pekerjaan

Kepada Perusahaan

Lain.

7) Peraturan

Menteri

Ketenagakerjaan

Republik Indonesia

Nomor 27 Tahun 2014

tentang Perubahan Atas

Peraturan Menteri

Tenaga Kerja Dan

Transmigrasi Nomor 19

Tahun 2012 tentang

Syarat-Syarat

Penyerahan Sebagian

Pelaksanaan Pekerjaan

Kepada Perusahaan

Lain.

b. Data Sekunder

Bahan hukum sekunder, yaitu berupa buku, artikel, laporan penelitan atau referensi lainnya yang ada kaitannya

dengan
Penyediaan

Jasa

Pekerja/Buruh.

4. Teknik Pengumpulan Data

Teknik pengumpulan data dilakukan secara sistematis dengan dengan suatu prosedur yang terstandar.

5. Teknik analisis Data Metode yang digunakan adalah analisis kualitatif.

\section{PEMBAHASAN}

\section{PERUSAHAAN PENYEDIAAN}

\section{JASA PEKERJA/BURUH}

Perusahaan penyedia jasa pekerja/buruh adalah perusahaan yang berbentuk badan hukum Perseroan Terbatas (PT) yang memenuhi syarat untuk melaksanakan kegiatan jasa penunjang perusahaan pemberi pekerjaan.

Perusahaan penyedia jasa pekerja/buruh lebih dikenal dengan istilah Outsourcing, yaitu suatu bentuk penyerahan dari kegiatan perusahaan kepada pihak lain, sehingga proses tersebut diharapkan outsourcing mampu memberikan hasil berupa 
peningkatan kinerja yang kompetitif di dalam menghadapi perkembangan ekonomi dan juga teknologi global. ${ }^{6}$

Wikipedia Mengartikan outsourcing sebagai suatu bentuk pemindahan pekerjaan dari perusahaan yang satu ke perusahaan yang lainnya. Biasanya proses ini dilakukan untuk memperkecil biaya produksi ataupun dilakukan untuk memusatkan suatu perhatian kepada hal yang lebih utama dari perusahaan tersebut.

Berdasarkan Undang-

Undang Nomor 13 Tahun 2003 tentang Ketenagakerjaan Pasal 66 (3), bahwa penyedia jasa pekerja/buruh merupakan bentuk usaha yang berbadan hukum dan memiliki izin dari instansi yang bertanggungjawab di bidang ketenagakerjaan. $^{7}$

\footnotetext{
Indonesiastudents.com, 10

Pengertian Outsourcing Menurut Para Ahli Lengkap,

http://www.indonesiastudents.com/pengerti an-outsourcing-menurut-para-ahli/.

7 Indonesia Legal Center Publishing, Ketenagakerjaan \& Penyelesaian Perselisihan Hubungan Industrial, (Jakarta: CV Karya Gemilang, 2011), HIm. 30.
}

Ketentuan

tersebut

dipertegas kembali dalam

Peraturan Menteri Tenaga Kerja dan Transmigrasi Republik Indonesia Nomor 19 Tahun 2012 tentang Syarat-Syarat Penyerahan Sebagian Pelaksanaan Pekerjaan Kepada Perusahaan Lain, khususnya dalam Pasal 1 (3): Perusahaan penyedia jasa pekerja/buruh adalah perusahaan yang berbentuk badan hukum Perseroan Terbatas (PT) yang memenuhi syarat untuk melaksanakan kegiatan jasa penunjang perusahaan pemberi kerja.

Pasal 2: Penyerahan sebagian pelaksanaan pekerjaan kepada perusahaan lain dapat dilakukan melalui perjanjian pemborongan pekerjaan atau perjanjian penyediaan jasa pekerja/buruh

Pasal 24: Perusahaan penyedia jasa pekerja/buruh harus memenuhi persyaratan:

a. Berbentuk badan hukum Perseroan Terbatas (PT) yang didirikan berdasarkan 
peraturan

perundang-

undangan;

b. Memiliki tanda daftar perusahaan;

c. Memiliki izin usaha;

d. Memiliki bukti wajib lapor ketenagakerjaan di perusahaan;

e. Memiliki izin operasional;

f. Mempunyai kantor dan alamat tetap; dan

g. Memiliki Nomor Pokok Wajib Pajak (NPWP) atas nama perusahaan.

\section{PERJANJIAN KERJA/KONTRAK KERJA}

Kontrak kerja adalah suatu perjanjian antara pekerja dan pengusaha secara lisan dan/atau tulisan, baik untuk waktu tertentu maupun untuk waktu tidak tertentu yang memuat syarat-syarat kerja, hak dan kewajiban. Setiap perusahaan wajib memberikan kontrak kerja di hari pertama pekerja/buruh bekerja. Dalam kontrak kerja biasanya terpapar dengan jelas pekerja/buruh memiliki hak mendapat kebijakan perusahaan yang sesuai dengan
Undang- undang Ketenagakerjaan yang berlaku di Indonesia. Di dalamnya juga memuat mengenai prosedur kerja dan kode disiplin yang ditetapkan perusahaan.

Pasal 1601a Kitab UndangUndang Hukum Perdata dapat dikatakan bahwa yang dinamakan kontrak kerja harus memenuhi persyaratan-persyaratan sebagai berikut:

1. Adanya pekerja/buruh dan pemberi kerja.

2. Pelaksanaan Kerja

3. Waktu Tertentu

4. Adanya Upah yang diterima Syarat sahnya kontrak kerja Pasal 1338 ayat (1) menyatakan bahwa perjanjian yang mengikat hanyalah perjanjian yang sah. Supaya sah pembuatan perjanjian harus mempedomani Pasal 1320 KUH Perdata. Pasal $1320 \mathrm{KUH}$ Perdata menentukan syarat sahnya kontrak kerja yaitu adanya :

a. Kesepakatan

b. Kewenangan

c. Objek yang diatur harus jelas

d. Sebab yang halal 
Dalam Peraturan Menteri

Tenaga Kerja dan Transmigrasi

Republik Indonesia Nomor 19

Tahun 2012 tentang Syarat-Syarat

Penyerahan

Sebagian

Pelaksanaan Pekerjaan Kepada

Perusahaan Lain, maka perjanjian

kerja dibuat secara tertulis.

Pasal 19:

Perjanjian penyediaan jasa pekerja/buruh sebagaimana dimaksud dalam Pasal 17 ayat (1) sekurang-kurangnya memuat:

a. Jenis pekerjaan yang akan dilakukan oleh pekerja/buruh dari perusahaan penyedia jasa pekerja/buruh;

b. Penegasan bahwa perusahaan penyedia jasa pekerja/buruh bersedia menerima pekerja/buruh dari perusahaan penyedia jasa pekerja/buruh sebelumnya untuk jenis pekerjaan yang terus menerus ada di perusahaan pemberi pekerjaan dalam hal terjadi penggantian perusahaan penyedia jasa pekerja/buruh; dan c. Hubungan kerja antara perusahaan penyedia jasa pekerja/buruh dengan pekerja/buruh yang dipekerjakannya berdasarkan perjanjian kerja waktu tidak tertentu atau perjanjian kerja waktu tertentu.

\section{Pasal 30}

Dalam hal perjanjian kerja waktu tertentu tidak memuat ketentuan sebagaimana dimaksud dalam Pasal 28 dan Pasal 29, maka hubungan kerja antara perusahaan penyedia jasa pekerja/buruh dengan pekerja/buruh berubah menjadi hubungan kerja yang didasarkan atas perjanjian kerja waktu tidak tertentu sejak ditandatanganinya perjanjian kerja yang tidak memenuhi persyaratan.

\section{Pasal 31}

Dalam hal pekerja/buruh tidak memperoleh jaminan kelangsungan bekerja, maka pekerja/buruh dapat mengajukan gugatan kepada Pengadilan Hubungan Industrial. 
Pasal 32

1) Dalam hal perusahaan pemberi pekerjaan tidak melanjutkan perjanjian penyediaan jasa pekerja/buruh dan mengalihkan pekerjaan penyediaan jasa pekerja/buruh kepada perusahaan penyedia jasa pekerja/buruh yang baru, maka perusahaan penyedia jasa pekerja/buruh yang baru, harus melanjutkan perjanjian kerja yang telah ada sebelumnya tanpa mengurangi ketentuan yang ada dalam perjanjian kerja yang telah disepakati.

2) Dalam hal terjadi pengalihan pekerjaan kepada perusahaan penyedia jasa pekerja/buruh yang baru sebagaimana dimaksud pada ayat (1), maka masa kerja yang telah dilalui para pekerja/buruh pada perusahaan penyedia jasa pekerja/buruh yang lama harus tetap dianggap ada dan diperhitungkan oleh perusahaan penyedia jasa pekerja/buruh yang baru.
Dalam Undang-Undang Nomor 13 Tahun 2003 tentang Ketenagakerjaan diatur mengenai perjanjian kerja sebagai berikut:

Pasal 1 (14) Perjanjian kerja adalah perjanjian antara pekerja/buruh dengan mengusaha atau pemberi kerja yang memuat syarat-syarat kerja, hak dan kewajiban para pihak. ${ }^{8}$

\section{PENGATURAN PENYEDIAAN} JASA PEKERJA/BURUH PADA PERUSAHAAN

Ketentuan pemborongan pekerjaan diatur dalam Pasal 1601 b Kitab Undang-Undang Hukum Perdata, namun dalam Pasal tersebut belum diatur mengenai perlindungan bagi pekerja/buruh yang dipekerjakan melalui pemborongan pekerjaan maupun penyediaan jasa pekerja/buruh. Oleh karena itu, Undang-Undang Nomor 13 Tahun 2003 tentang Ketenagakerjaan mengatur mengenai penyerahan sebagian

\footnotetext{
8 Indonesia Legal Center Publishing, Ketenagakerjaan \& Penyelesaian Perselisihan Hubungan Industrial, (Jakarta: CV Karya Gemilang, 2011).
} 
pelaksanaan pekerjaan kepada

perusahaan lain.

Dalam

ketentuan ini telah diajukan permohonan judicial review dan telah diputus oleh Mahkamah Konstitusi dengan Putusan Nomor 27/PUU-IX/2011 yang mengamanatkan adanya jaminan kelangsungan kerja serta syaratsyarat perlindungan bagi pekerja/buruh yang bekerja pada perusahaan penerima pemborongan maupun perusahaan penyedia jasa pekerja/buruh. Berdasarkan Putusan Mahkamah Konstitusi tersebut, Pemerintah menyempurnakan Keputusan Menteri Tenaga Kerja dan Transmigrasi Nomor KEP.101/MEN/VI/2004 tentang Tata Cara Perijinan Perusahaan Penyedia Jasa Pekerja/Buruh dan Keputusan Menteri Tenaga Kerja dan Transmigrasi Nomor KEP.220/MEN/X/2004 tentang Syarat-Syarat Penyerahan Sebagian Pelaksanaan Pekerjaan Kepada Perusahaan Lain menjadi Peraturan Menteri Tenaga Kerja dan Transmigrasi Nomor 19 Tahun
2012 tentang Syarat-Syarat

Penyerahan

Sebagian

Pelaksanaan Pekerjaan Kepada Perusahaan Lain.

Dalam rangka optimalisasi pelaksanaan penyerahan sebagian pelaksanaan pekerjaan kepada perusahaan lain sebagaimana diatur dalam Peraturan Menteri Tenaga Kerja dan Transmigrasi Nomor 19 Tahun 2012 tersebut, maka disusunlah Pedoman Pelaksanaannya dalam Surat Edaran Menteri Tenaga Kerja Dan Transmigrasi Republik Indonesia Nomor SE.04/MEN/VIII/2013 tentang Pedoman Pelaksanaan Peraturan Menteri Tenaga Kerja Dan Transmigrasi Republik Indonesia Nomor 19 Tahun 2012 Tentang Syarat-Syarat Penyerahan Sebagian Pelaksanaan Pekerjaan Kepada Perusahaan Lain.

\begin{tabular}{|c|c|c|}
\hline Dalam & Surat & Edaran \\
\hline tersebut, & Penyediaan & Jasa \\
\hline \multicolumn{3}{|c|}{ Pekerja/Buruh diatur dalam Bab III } \\
\hline Penyerahan & & Sebagian \\
\hline Pelaksanaan & Pekerjaan & Melalui \\
\hline Perjanjian & Penyediaan & Jasa \\
\hline
\end{tabular}


A. Persyaratan Perusahaan Penyedia Jasa Pekerja/Buruh

a. Berbentuk badan hukum Perseroan Terbatas (PT) yang didirikan berdasarkan peraturan perundangundangan.

b. Memiliki tanda daftar perusahaan sesuai peraturan perundangundangan.

c. Memiliki surat izin usaha sesuai peraturan perundang-undangan.

d. Memiliki bukti wajib lapor ketenagakerjaan yang dikeluarkan oleh instansi yang bertanggung jawab di bidang ketenagakerjaan kabupaten/kota.

e. Memiliki izin operasional yang dikeluarkan oleh instansi yang bertanggung jawab di bidang ketenagakerjaan provinsi.

f. Mempunyai kantor dan alamat tetap.

g. Memiliki nomor pokok wajib pajak (NPWP) atas nama perusahaan.
B. Persyaratan

Perjanjian

Penyediaan

Jasa

Pekerja/Buruh

1. Perjanjian penyediaan jasa pekerja/buruh dibuat secara tertulis.

2. Pekerjaan yang dapat diserahkan kepada perusahaan penyedia jasa pekerja/buruh harus merupakan kegiatan jasa penunjang atau yang tidak berhubungan langsung dengan proses produksi, meliputi:

i. Usaha pelayanan kebersihan (cleaning service);

ii. Usaha penyediaan makanan bagi pekerja/buruh (catering);

iii. Usaha tenaga pengaman (security/satuan pengamanan);

iv. Usaha jasa penunjang di pertambangan dan perminyakan; dan

v. Usaha penyediaan angkutan bagi pekerja/buruh. 
3. Perusahaan penyedia jasa

berdasarkan Perjanjian pekerja/buruh di larang menyerahkan pelaksanaan sebagian atau seluruh pekerjaan yang diperjanjikannya kepada perusahaan penyedia jasa pekerja/buruh lain.

4. Memuat jenis pekerjaan yang akan dilakukan oleh pekerja/buruh dari perusahaan penyedia jasa pekerja/buruh.

5. Memuat penegasan bahwa perusahaan penyedia jasa pekerja/buruh bersedia menerima pekerja/buruh dari perusahaan penyedia jasa pekerja/buruh sebelumnya untuk jenis pekerjaan yang terus menerus ada di perusahaan pemberi pekerjaan dalam hal terjadi penggantian perusahaan penyedia jasa pekerja/buruh.

6. Memuat penjelasan mengenai hubungan kerja antara perusahaan penyedia jasa pekerja/buruh dengan pekerja/buruh (PKWT) atau Perjanjian Kerja Waktu Tidak Tertentu (PKWTT).

$\begin{array}{lr}\text { REPOSISI PENYEDIAAN } & \text { JASA } \\ \text { PEKERJA/BURUH } & \text { PADA } \\ \text { PERUSAHAAN } & \text { PASCA } \\ \text { PUTUSAN MAHKAMAH } & \text { AGUNG } \\ \text { NOMOR } & 1438 \\ \text { K/PDT.SIS.PHI/2017 } & \end{array}$

$\begin{array}{rrr}\text { Baik } & \text { Putusan } & \text { Pengadilan } \\ \text { Negeri } & \text { maupun } & \text { Putusan }\end{array}$ Mahkamah Agung memenangkan pekerja/buruh. Hal ini dikarenakan perusahaan pemberi kerja telah melakukan kesalahan secara normatif dalam penerimaan pekerja/buruh menjadi pekerja/buruh di perusahaan penyedia jasa pekerja/buruh, yaitu:

1. Pekerjaan yang diborongkan kepada perusahaan penyedia jasa pekerja/buruh, yaitu pada bagian petugas pelayanan dan penjual tiket pesawat adalah merupakan pekerjaan utama pada perusahaan pemberi kerja, sehingga tidak boleh 
diserahkan

kepada

perusahaan lain.

2. Perjanjian kerja antara perusahaan penyedia jasa pekerja/buruh dengan pekerja/buruh tidak pernah dibuat oleh perusahaan penyedia jasa pekerja/buruh dan tidak pernah ditandatangani oleh pekerja/buruh.

3. Perusahaan pemberi kerja memutus hubungan kerja dengan pekerja/buruh melalui perusahaan penyedia jasa pekerja/buruh tanpa memberikan hak-hak pekerja/buruh sesuai dengan peraturan yang berlaku.

Pasca adanya Putusan Mahkamah Agung Nomor 1438 K/PDT.SIS.PHI/2017 maka posisi penyediaan jasa pekerja/buruh seperti yang diatur dalam UndangUndang Republik Indonesia Nomor 13 tahun 2003 tentang Ketenagakerjaan, serta peraturan pelaksanaannya dalam Peraturan Menteri Tenaga Kerja, Keputusan Menteri Tenaga Kerja, dan Surat
Edaran Menteri Tenaga Kerja menjadi lebih kuat, dan untuk menjadi perhatian bagi perusahaan pemberi kerja maupun kepada perusahaan penyedia jasa pekerja/buruh, bahwa tidak semua jenis pekerjaan dapat diserahkan kepada perusahaan lain, dan harus dilaksanakan sesuai dengan ketentuan yang telah ditetapkan.

Dengan adanya Putusan Mahkamah Agung Nomor 1438 K/PDT.SUS.PHI/2017

menegaskan kembali bahwa pekerja/buruh dari perusahaan penyedia jasa pekerja/buruh berhak mendapat perlindungan kerja sesuai dengan Pasal 65 Ayat (4) dan Pasal 66 Ayat (2) UndangUndang Republik Indonesia Nomor 13 Tahun 2003 tentang Ketenagakerjaan.

Dengan demikian, baik perusahaan penyedia jasa pekerja/buruh maupun perusahaan yang mengalihkan sebagian pekerjaan kepada pihak ketiga wajib melindungi pekerja/buruh tanpa memperhatikan status pekerja/buruh tersebut. 
Tuntutan penghapusan

sistem kerja outsourcing dari pihak buruh, mendapat perlawanan yang keras dari pengusaha. Muncullah dilema pengaturan outsourcing. Bagi buruh outsourcing adalah sumber kegelisahan sosial. Outsourcing dianggap sebagai sumber diskriminasi pemberian hak (terhadap pekerja tetap) yang menjadi sumber utama hambatan mencapai kesejahteraan. Bagi pengusaha, outsourcing adalah suatu sistem kerja yang sangat menguntungkan untuk mencapai efesiensi guna peningkatan produktivitas. Bagi pemerintah, outsourcing merupakan salah satu solusi guna mengatasi tingkat pengangguran dan pemikat investasi.

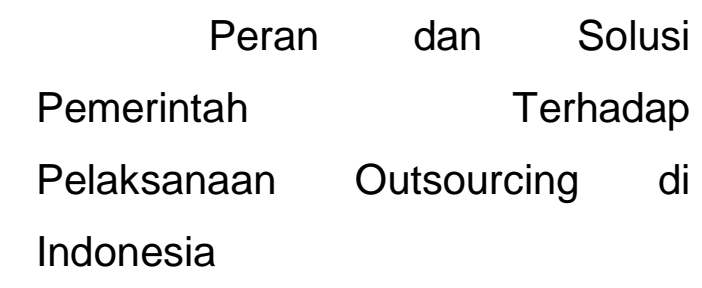

1. Pertama, pemerintah harus melakukan pengawasan dan menetapkan standar regulasi di tingkat pusat dan daerah. Pemerintah juga harus memastikan semua regulasi dapat diimplementasikan, bukan malah menimbulkan polemik di lapangan.

2. Kedua, pengusaha atau industri diharap membuat skema hubungan kerjasama yang melindungi hak pekerja atau buruh. Perusahaan seharusnya menetapkan outsourcing bukan untuk cost reduction tetapi semangat untuk fokus pada bisnis dan produktivitas yang berkaitan dengan kesejahteraan.

3. Ketiga, perusahaan outsourcing harus profesional dan taat hukum sehingga dapat menjadi mitra usaha yang dapat diandalkan berdasarkan kompetensi dan produktifitasnya.

4. Keempat, pekerja atau buruh harus meningkatkan kompetensinya agar mampu bersaing di tengah era yang kompetitif sehingga akan dicari perusahaan dan mempunyai daya saing. Selain itu juga agar segera dibuat badan independen atau rumusan besarnya iuran pesangon 
untuk dapat memenuhi hakhak pekerja jika tidak dapat melanjutkan

hubungan

kerjanya.

\section{KESIMPULAN}

1. Perusahaan dapat menyerahkan sebagian pelaksanaan pekerjaan kepada Perusahaan Penyedia Jasa Pekerja/Buruh yang berbentuk Badan Hukum (PT).

Perjanjian penyediaan jasa pekerja/buruh dibuat secara tertulis.

Pekerjaan yang dapat diserahkan kepada perusahaan penyedia jasa pekerja/buruh harus merupakan kegiatan jasa penunjang atau yang tidak berhubungan langsung dengan proses produksi, meliputi:
a. Usaha
pelayanan
kebersihan
(cleaning
service);
b. Usaha
penyediaan
makanan
bagi
pekerja/buruh (catering);

c. Usaha tenaga pengaman (security/satuan pengamanan);

d. Usaha jasa penunjang di pertambangan dan perminyakan; dan
e. Usaha penyediaan angkutan bagi pekerja/buruh.

Hubungan kerja antara perusahaan penyedia jasa pekerja/buruh dengan pekerja/buruh yang dipekerjakannya berdasarkan Perjanjian Kerja Waktu Tertentu (PKWT) atau Perjanjian Kerja Waktu Tidak Tertentu (PKWTT).

Sanksi apabila perusahaan pemberi kerja tidak melaksanakan ketentuan peraturan perundangan yang berlaku:

a. Hubungan kerja antara pekerja/buruh beralih dari hubungan kerja pekerja/buruh dengan Perusahaan Penyedia Jasa Pekerja/Buruh menjadi hubungan kerja 
pekerja/buruh dengan

perusahaan pemberi kerja.

b. Perjanjian Kerja Waktu

Tertentu (PKWT) antara

Perusahaan Penyedia

Jasa Pekerja/Buruh

dengan pekerja/buruh

berubah menjadi Perjanjian

Kerja Waktu Tidak Tertentu

(PKWTT)

antara

perusahaan pemberi kerja dengan pekerja/buruh, sejak awal pekerja/buruh bekerja.

2. Pasca adanya Putusan Mahkamah Agung Nomor 1438 K/PDT.SIS.PHI/2017 maka posisi penyediaan jasa pekerja/buruh seperti yang diatur dalam Undang-Undang Republik Indonesia Nomor 13 tahun 2003 tentang Ketenagakerjaan, serta peraturan pelaksanaannya dalam Peraturan Menteri Tenaga Kerja, Keputusan Menteri Tenaga Kerja, dan Surat Edaran Menteri Tenaga Kerja menjadi lebih kuat, dan untuk menjadi perhatian bagi perusahaan pemberi kerja maupun kepada perusahaan penyedia jasa pekerja/buruh, bahwa tidak semua jenis pekerjaan dapat diserahkan kepada perusahaan lain, dan harus dilaksanakan sesuai dengan ketentuan yang telah ditetapkan.

Tuntutan penghapusan sistem kerja outsourcing dari pihak buruh, mendapat perlawanan yang keras dari pengusaha. Muncullah dilema pengaturan outsourcing. Bagi buruh outsourcing adalah sumber kegelisahan sosial. Outsourcing dianggap sebagai sumber diskriminasi pemberian hak (terhadap pekerja tetap) yang menjadi sumber utama hambatan mencapai kesejahteraan. Bagi pengusaha, outsourcing adalah suatu sistem kerja yang sangat menguntungkan untuk mencapai efesiensi guna peningkatan produktivitas. Bagi pemerintah, outsourcing merupakan salah satu solusi guna mengatasi tingkat 
pengangguran dan pemikat

investasi.

Peran dan Solusi Pemerintah

Terhadap Pelaksanaan

Outsourcing di Indonesia

1) Pertama, pemerintah harus melakukan pengawasan dan menetapkan standar regulasi di tingkat pusat dan daerah. Pemerintah juga harus memastikan semua regulasi dapat diimplementasikan, bukan malah menimbulkan polemik di lapangan.

2) Kedua, pengusaha atau industri diharap membuat skema hubungan kerjasama yang melindungi hak pekerja atau buruh. Perusahaan seharusnya menetapkan outsourcing bukan untuk cost reduction tetapi semangat untuk fokus pada bisnis dan produktivitas yang berkaitan dengan kesejahteraan.

3) Ketiga, perusahaan outsourcing harus profesional dan taat hukum sehingga dapat menjadi mitra usaha yang dapat diandalkan berdasarkan kompetensi dan produktifitasnya.

4) Keempat, pekerja atau buruh harus meningkatkan kompetensinya agar mampu bersaing di tengah era yang kompetitif sehingga akan dicari perusahaan dan mempunyai daya saing. 


\section{DAFTAR PUSTAKA}

Direktori Putusan Mahkamah Agung Republik Indonesia, Putusan Nomor 204/Pdt.Sus-PHI/2016/PN Mdn, https://putusan.mahkamaha gung.go.id/main/pencarian/? $\mathrm{q}=204 \% 2 \mathrm{FPdt}$.SusPHI\%2F2016\%2FPN+Mdn.

Direktori Putusan Mahkamah Agung Republik Indonesia, Putusan Mahkamah Agung Nomor 1438 K/Pdt.Sus$\mathrm{PHI} / 2017$,

https://putusan.mahkamaha gung.go.id/putusan/dcb3247 c790c82a6837ca37ae7a5f4 $\underline{76 / .}$

Jaringan Dokumentasi Dan Informasi Hukum, Surat Edaran Menteri Tenaga Kerja Dan Transmigrasi Republik Indonesia Nomor: SE.04/MEN/VIII/2013 tentang Pedoman Pelaksanaan Peraturan Menteri Tenaga Kerja Dan Transmigrasi Republik
Indonesia Nomor 19 Tahun 2012 tentang Syarat-Syarat Penyerahan Sebagian Pelaksanaan Pekerjaan Kepada Perusahaan Lain, https://jdih.kemnaker.go.id/d ata puu/SE 04 2013.PDF.

Indonesiastudents.com, 10 Pengertian Outsourcing Menurut Para Ahli Lengkap, http://www.indonesiastudent s.com/pengertianoutsourcing-menurut-paraahli/.

Indonesia Legal Center Publishing, Ketenagakerjaan \& Penyelesaian Perselisihan Hubungan Industrial, (Jakarta: CV Karya Gemilang, 2011).

Kitab Undang-Undang Hukum

Perdata.

Redaksi Bmedia, UUD 1945 \& Perubahannya; Reshuffle Kabinet Kerja (2014-2019), (Jakarta: Bmedia Imprint Kawan Pustaka, 2017), HIm. 30. 